spread of bird gardens is so modern that it was not apparent when Dr Bijleveld was researching the facts, for this book is, incidentally, his thesis for a doctorate degree.

The chapter on the decline and the present situation is the longest and by far the most dismal. Almost the only gleam of hope is in the United Kingdom where the status of the golden eagle, peregrine falcon and kite have improved following the control of organochlorine pesticides-not the control of illegal shooting on the game estates. Maarten Bijleveld thinks that there is a growing realisation of the plight of birds of prey and that some protective measures are already being taken, although some species are doomed. He concludes by stressing the importance of a coordinated plan of campaign for the protection of raptors and for public education.

This is an important book which will be the base line for studying future trends. It has a very comprehensive bibliography. But the price is high.

PETER CONDER

\title{
The Mammals of Canada, by A. W. F. Banfield. University of Toronto Press, $\$ 19.95$.
}

In print at last, this book has been 50 years in gestation. Nothing comparable on Canada's impressive share in the nearctic mammal fauna has appeared since Ernest Thompson Seton's Life Histories of Northern Animals in 1909, written when he was naturalist to the government of Manitoba. Great credit goes to Professor Frank Banfield for bringing to completion the task on which his three predecessors, as curator of mammals at the National Museum in Ottawa, all laboured in turn. While they amassed data and wrote checklists and papers, the implantation of their embryo was interminably delayed, until 1961 when Banfield took over. In the end therefore it is very much his book: the writing all remained to him and is greatly enriched by his personal experience.

A quarto volume of some 460 double-column pages, it is intended as a work of reference, and deals systematically with 196 species (including 33 cetaceans). The bulk of the account devoted to each species pertains to natural history, and although its style is economical it is often packed with interesting reading. Each species has a map, usually $7 \frac{1}{2} \times 6$ inches, filling more than half a page, to show its Canadian distribution, with a smaller inset of the nearctic or holarctic regions, as necessary, to indicate the world range. Such large maps allow subspecific ranges to be shown; in total they present a prodigious quantity of detail. Key references to research papers are given. There are colour plates depicting 75 species, and over 100 text-figures.

I formed two general impressions from the book. The first is the mammalian variety and wealth of this largely boreal land, confirming what I knew already from my long residence and persistent travels within it. The second is the difference that Canada is able to show, from the depressing picture of human predation, dwindling wildlife and habitat destruction so widespread in today's world. Inroads and devastations there have been, some on a ruthless scale; but they were mostly long ago, and were halted and the decline reversed before it was too late. The blackfooted ferret seems to be the only mammal lost to Canada this century. The sea otter, we are told, has been reintroduced. The slaughter of harp seals is restricted by law, and the population now whelping in the Gulf of St. Lawrence alone is estimated at 450,000. The mountain lions are now known to have survived in the forests of New Brunswick, as well as being widespread in the Rocky Mountains and British Columbia. Even the bowhead whales are said to be slowly recovering in the Canadian Arctic, though confirming data are lacking. (The right whale is still 'very rare'.) The vastness of the forests and mountains, the muskegs and barren grounds, is on her side, but Canada has done uncommonly well in practical conservation. Long may it continue, in an age when airplanes and skidoos can go anywhere, and new roads progressively lay open the recesses of the north. There must be no relaxation.

V. C. WYNNE-EDWARDS 